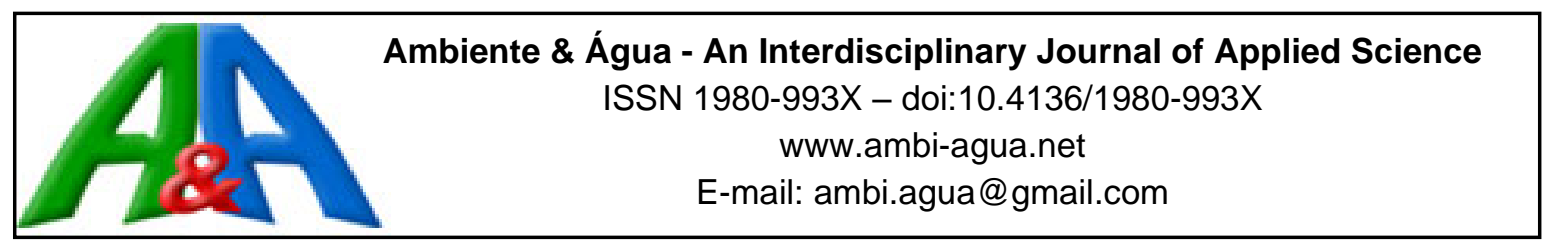

\title{
Moringa oleifera seed husks for methylene blue dye adsorption: kinetic, equilibrium, and thermodynamic analyses
}

ARTICLES doi:10.4136/ambi-agua.2812

Received: 04 Nov. 2021; Accepted: 11 Jan. 2022

\section{Carolina Almeida Lopes ${ }^{(D}$; Cely Roledo ${ }^{(D}$; Adriano Gonçalves dos Reis* ${ }^{(D}$}

\author{
Instituto de Ciência e Tecnologia. Departamento de Engenharia Ambiental. Universidade Estadual Paulista \\ (UNESP), Estrada Doutor Altino Bondensan, n 500, São José dos Campos, SP, Brazil. \\ E-mail: carolina.lopes@unesp.br, cely.roledo@unesp.br \\ *Corresponding author. E-mail: adriano.reis@unesp.br
}

\begin{abstract}
M. oleifera seed husks (H-MO) were used as adsorbent for the removal of methylene blue (MB) dye from an aqueous solution. The adsorbent was characterized by SEM, EDX, XRD, FTIR, BET, and pHPzc. To evaluate adsorption capacity, the influences of $\mathrm{pH}$, kinetics, isotherms, and thermodynamic properties were analyzed. Characterization techniques indicated that $\mathrm{H}-\mathrm{MO}$ has heterogeneous morphological characteristics with a specific surface area of 3.24 $\mathrm{m}^{2} \mathrm{~g}^{-1}$, mainly composed of cellulose distributed in an amorphous structure. MB adsorption was favorable at $\mathrm{pH}$ values higher than $\mathrm{pH}_{\mathrm{PZC}}$ of 6.6 , using an adsorbent dosage of $1.0 \mathrm{~g} \mathrm{~L}^{-1}$. Equilibrium was achieved in the first $240 \mathrm{~min}$, and the pseudo-second-order model was suitable for describing the kinetic data. Freundlich was the most adequate model for describing the isotherm curves, predicting a maximum adsorption capacity of $122.7 \mathrm{mg} \mathrm{g}^{-1}$ at $24^{\circ} \mathrm{C}$, higher than other natural adsorbents. The adsorption process was spontaneous and exothermic, indicating that lower temperatures favor the adsorption and that it is controlled by physical forces. The data presented indicate the MB has the potential to be successfully treated by the eco-friendly and low-cost adsorbent $M$. oleifera seed husks.
\end{abstract}

Keywords: agricultural wastes, low-cost adsorbent, physisorption.

\section{Cascas da semente de Moringa oleifera para adsorção do corante azul de metileno: análise cinética, de equilíbrio e termodinâmica}

\section{RESUMO}

Cascas de sementes de $M$. oleifera (H-MO) foram usadas como adsorvente para remover o corante azul de metileno (MB) de uma solução aquosa. $\mathrm{O}$ adsorvente foi caracterizado por MEV, EDS, DRX, FTIR, BET e pHPCZ. Para avaliar a capacidade de adsorção, foi analisada a influência do $\mathrm{pH}$, cinética, isotermas e propriedades termodinâmicas. Técnicas de caracterização indicaram que a H-MO possui características morfológicas heterogêneas com área superficial específica de $3,24 \mathrm{~m}^{2} \mathrm{~g}^{-1}$, composta principalmente por celulose distribuída em estrutura amorfa. A adsorção de MB foi favorável em valores de $\mathrm{pH}$ superiores a $\mathrm{pH}$ PCZ de 6,6, utilizando uma dosagem de adsorvente de $1,0 \mathrm{~g} \mathrm{~L}^{-1}$. $\mathrm{O}$ equilíbrio foi alcançado nos primeiros 240 min, e o modelo de pseudo segunda ordem foi adequado para descrever os dados cinéticos. Freundlich foi o modelo mais adequado para descrever as curvas isotérmicas, prevendo uma capacidade máxima de adsorção de $122,7 \mathrm{mg} \mathrm{g}^{-1}$ a $24^{\circ} \mathrm{C}$, superior a outros adsorventes naturais.

This is an Open Access article distributed under the terms of the Creative Commons Attribution License, which permits unrestricted use, distribution, and reproduction in any medium, provided the original work is properly cited. 
O processo de adsorção foi espontâneo e exotérmico, indicando que temperaturas mais baixas favorecem a adsorção e que ela é controlada por forças físicas. Os dados apresentados indicam que o MB tem potencial para ser tratado com sucesso pelas cascas de sementes de M. oleifera, um adsorvente ecologicamente favorável e de baixo custo.

Palavras-chave: adsorventes de baixo custo, fisissorção, resíduos agrícolas.

\section{INTRODUCTION}

In the last decades, a growing interest in the use of alternative, low-cost adsorbents (LCAs) has been observed. LCAs are classified as natural materials (e.g., wood, coal, clays), industrial wastes/by-products (e.g., fly ash, red mud), and agricultural wastes/by-products (e.g., seed, seed husk, corn cob waste) (Gupta et al., 2009). In this sense, the seed husk of Moringa oleifera is included as agricultural waste. This plant has several applications in the food, pharmaceutical, cosmetics, and food nutrition industries due to its properties (Ueda Yamaguchi et al., 2021). Also, for many years, several studies have been investigating the potential of its seeds in drinking water treatment (Ribeiro et al., 2019), and in domestic (Vega Andrade et al., 2021) and industrial wastewater treatment (Villaseñor-Basulto et al., 2018) due to its coagulant properties. In addition to its use as a coagulant, $M$. oleifera seed has also been investigated as an alternative in the treatment of drinking water and wastewater as an adsorbent, for example, in the removal of heavy metals (Araújo et al., 2013) and dyes (Reck et al., 2018). However, the use of the M. oleifera seed generates the seed's husk waste. The potential advancement in the use of this seed as a coagulant and adsorbent on a commercial scale requires better management of its waste (husk) through the evaluation of possible scientific and technological applications.

The use of $M$. oleifera seed husk has not proved to be efficient as a coagulant (Kansal and Kumari, 2014). However, recent studies have been conducted to evaluate the possibility of using the husk as an adsorbent to remove pollutants from water, such as atrazine herbicide (Cusioli et al., 2019), acetaminophen analgesic (Quesada et al., 2019), diuron pesticide (Bezerra et al., 2018), trihalomethanes (Okoya et al., 2020), and cyanobacterial hepatotoxin microcystinLR (Warhurst et al., 1997). The capacity of $M$. oleifera seed husk to remove those pollutants shows its potential application as a LCA in the treatment of drinking water and wastewater, and new studies for removal of different problematic pollutants are required, such as dyes from textile wastewaters.

Dye industry effluents, when not properly treated, can cause an oxygen imbalance in ecosystems by dissolved oxygen depletion, in addition to preventing sunlight penetration, thereby altering the photosynthetic activity of the environment, which results in water quality deterioration and, consequently, in adverse effects to the local fauna and flora (Yagub et al., 2014). Methylene blue (MB) dye is a synthetic and cationic dye, from the group of thiazines, soluble in water and widely used in the textile industry to color silk, cotton, wool, leather, and paper coating. This dye shows toxicity such as teratogenicity, mutagenicity, neurotoxicity, nucleic acid damage, etc. (Sabnis, 2010) An aggravating factor is that dyes are resistant to degradation, and this property becomes an obstacle to effluent treatment, since they are substances that have highly stable chemical structures, making their removal difficult whether by biological, chemical, or physical process (Yagub et al., 2014). Several methods are used for the removal of dyes from wastewater, such as adsorption, coagulation, advanced oxidation, and membrane separation (Gupta et al., 2009). Many textile industries use commercial activated carbon for the treatment of dye waste, as adsorption is one of the most effective processes of advanced wastewater treatment (Yagub et al., 2014). Several types of adsorbents have been evaluated for MB dye removal as a cost-effective alternative to commercial activated carbons, such as the agricultural wastes/by-products LCAs apple pomace (Bonetto et al., 2021), 
Brazilian berry seeds (E. uniflora) (Georgin et al., 2020), and sorghum husk (Adeogun et al., 2019).

In this context, considering the need for better use of M. oleifera seed husk as a low-cost adsorbent from agricultural waste and the risks associated with the discharge of MB dye from an industrial effluent, a systematic investigation, including equilibrium, thermodynamics, kinetics, and mechanism of the adsorption of MB dye by $M$. oleifera seed husk, is a subject of interest and is discussed in this paper.

\section{MATERIAL AND METHODS}

\subsection{Adsorbent preparation and characterization}

Moringa oleifera seeds were purchased from Arbocenter, and the seeds were harvested in the city of Araçatuba (2056'19.72" S, 5040'6.17" W), São Paulo - Brazil. First, the seeds were manually peeled. Seed kernels were segregated for future studies related to oil extraction and further use as a coagulant. The husks were then washed with deionized water and dried in a SolidSteel's $42 \mathrm{~L}$ SSDc oven at $60^{\circ} \mathrm{C}$ for $24 \mathrm{~h}$. After drying, the husks were ground using a commercial blender and sieved to be standardized on a maximum particle size of $600 \mu \mathrm{m}$. The powder obtained was used as adsorbent, and hereinafter will be called "H-MO".

The surface functional groups of H-MO were determined by Fourier Transform Infrared (FTIR) Spectroscopy (Shimadzu IRAffinity-1), in which the samples were scanned in the region of $4000-650 \mathrm{~cm}^{-1}$, in transmittance mode. The structural properties of the powder samples were determined by X-ray diffractometer (Rigaku Ultima IV), equipped with $\mathrm{CuK} \alpha$ radiation $(\lambda=0.154 \mathrm{~nm})$ at $40 \mathrm{kV}, 30 \mathrm{~mA}$ and $2 \theta$ scan ranging from $5^{\circ}$ to $80^{\circ}$ with $2^{\circ} \mathrm{min}^{-1}$ step. Surface morphology was evaluated by scanning electron microscopy (SEM) (Tescan Vega 3 ), with $15.0 \mathrm{kV}$ acceleration voltage. The energy dispersive X-ray spectroscopy (EDX) provided the elemental analysis of the H-MO through the SEM coupled with the EDX detector (Oxford X-act). For this analysis, the samples were previously covered with gold at a thickness of approximately $25 \mathrm{~nm}$. The point of zero charge ( $\mathrm{pH}$ PZC) was measured by the salt addition method with $0.1 \mathrm{M} \mathrm{NaNO}$ (purity $\geq 98 \%$, Exxodo), proposed by Bakatula et al. (2018). To determine the specific surface area, the BET method was used by adsorption/desorption isotherms of $\mathrm{N}_{2}$ at $-196^{\circ} \mathrm{C}$ in a Nova $4200 \mathrm{e}$ (Quantachrome). Before the adsorption of $\mathrm{N}_{2}$, the samples were dried for $24 \mathrm{~h}$ at $60^{\circ} \mathrm{C}$ and subjected to degassing for $3 \mathrm{~h}$ at $90^{\circ} \mathrm{C}$.

\subsection{H-MO adsorption studies}

The adsorption assays were conducted using methylene blue dye (MB) hydrate (purity $\geq$ $82 \%$, Neon) as adsorbate. From a MB stock solution $\left(1 \mathrm{~g} \mathrm{~L}^{-1}\right)$, dilutions with demineralized water were made for the adsorption study. The experiments were conducted in triplicate in a batch mode on a thermostatic stirring bath (Dubnoff 304-TPA) at $100 \mathrm{rpm}$. After adsorption time, the solutions were then centrifuged (Excelsa II 206-BL) at 3,000 rpm for $5 \mathrm{~min}$ and the MB concentration was measured by UV-Vis spectrophotometer (Shimadzu UV 1800), operating at $\lambda_{\max }=664 \mathrm{~nm}$ wavelength. The percentage of dye removal $(R, \%$ - Equation 1$)$, adsorption capacity at any time $\left(q_{t}, \mathrm{mg} \mathrm{g}^{-1}\right.$ - Equation 2$)$ and at equilibrium $\left(q_{e}, \mathrm{mg} \mathrm{g}^{-1}\right.$ Equation 3) were calculated as follows:

$$
\begin{aligned}
& R=\frac{\left(C_{0}-C_{t}\right) 100}{C_{0}} \\
& q_{t}=\frac{\left(C_{0}-C_{t}\right) V}{m} \\
& q_{e}=\frac{\left(C_{0}-C_{e}\right) V}{m}
\end{aligned}
$$


Where $C_{0}$ is the initial concentration of $\mathrm{MB}, C_{t}$ is the concentration of $\mathrm{MB}$ at any time, $C_{e}$ is the equilibrium concentration of $\mathrm{MB}, V$ is the volume of solution, and $m$ is the mass of the adsorbent.

The H-MO dosage effect was analyzed for the values of $0.2,0.6,1.0,1.6,2.0,2.6,3.0$, and $4.0 \mathrm{~g} \mathrm{~L}^{-1}$. For these assays, the $\mathrm{pH}$ was set at 7.0. The different H-MO dosages were put in contact with $50 \mathrm{~mL}$ of $\mathrm{MB}$ solution with an initial concentration of $50 \mathrm{mg} \mathrm{L}^{-1}$. Since the equilibrium time was not determined yet, solutions were stirred during $1,200 \mathrm{~min}$ at $24^{\circ} \mathrm{C}$. Based on the percentage of dye removal (R), the ideal dosage of adsorbent for the next tests was determined.

The $\mathrm{pH}$ effect test was conducted for the $\mathrm{pH}$ values of 5.0, 6.0, 7.0, 8.0, and 9.0, using 1.0 $\mathrm{g} \mathrm{L}^{-1}$ of $\mathrm{H}-\mathrm{MO}$ adsorbent, previously defined by the dosage effect. The $\mathrm{pH}$ adjustments were made with $\mathrm{HNO}_{3} 0.1 \mathrm{M}$ (purity $\geq 66 \%$, LS Chemicals) or $\mathrm{NaOH} 0.1 \mathrm{M}$ (purity $99.67 \%$, Neon). $\mathrm{H}-\mathrm{MO}$ adsorbent was added to $50 \mathrm{~mL}$ of MB solutions with initial concentration of $50 \mathrm{mg} \mathrm{L}^{-1}$, and the solutions were stirred for $1,200 \mathrm{~min}$ at $24^{\circ} \mathrm{C}$.

The kinetic adsorption experiments were conducted using the best conditions found in the $\mathrm{pH}(9.0)$ and dosage $\left(1.0 \mathrm{~g} \mathrm{~L}^{-1}\right)$ tests. $\mathrm{H}-\mathrm{MO}$ adsorbent was added to $50 \mathrm{~mL}$ of MB solutions with an initial concentration of $50 \mathrm{mg} \mathrm{L}^{-1}$, and the solutions were agitated at $24^{\circ} \mathrm{C}$. Samples were collected at predefined times of 5, 20, 40, 60, 120, 240, 360, 480, 600, 720, and $1440 \mathrm{~min}$. Through adsorption kinetics, the equilibrium time was determined, which was used in the adsorption isotherm test.

The adsorption isotherms were determined by varying the initial $\mathrm{MB}$ concentration $(5,10$, $15,20,30,40,50,60,70,80$ and $\left.90 \mathrm{mg} \mathrm{L}^{-1}\right)$ in $50 \mathrm{~mL}$ of solution with dosage of adsorbent (1.0 $\left.\mathrm{g} \mathrm{L}^{-1}\right), \mathrm{pH}$ value $(\mathrm{pH}=9)$, and equilibrium time $(240 \mathrm{~min})$ previously determined. The temperatures evaluated were $24^{\circ} \mathrm{C}, 34^{\circ} \mathrm{C}$, and $44^{\circ} \mathrm{C}$.

\section{RESULTS AND DISCUSSION}

\subsection{H-MO adsorbent characterization}

The morphology H-MO's SEM images are shown in Figure 1, where non-uniform complex fiber matrix with no particular shape can be observed, in agreement with other authors (Araujo et al., 2018; Quesada et al., 2019). The overall H-MO chemical composition, as a result of semi-quantitative EDX spectrometry, presented a major presence of carbon (69.4\% of weight) and oxygen (30.4\% of weight), which are related to the natural organic structure of the lignocellulosic structure of the material, such as cellulose, hemicellulose, and lignin (Bezerra et al., 2018; Garcia-Fayos et al., 2016).

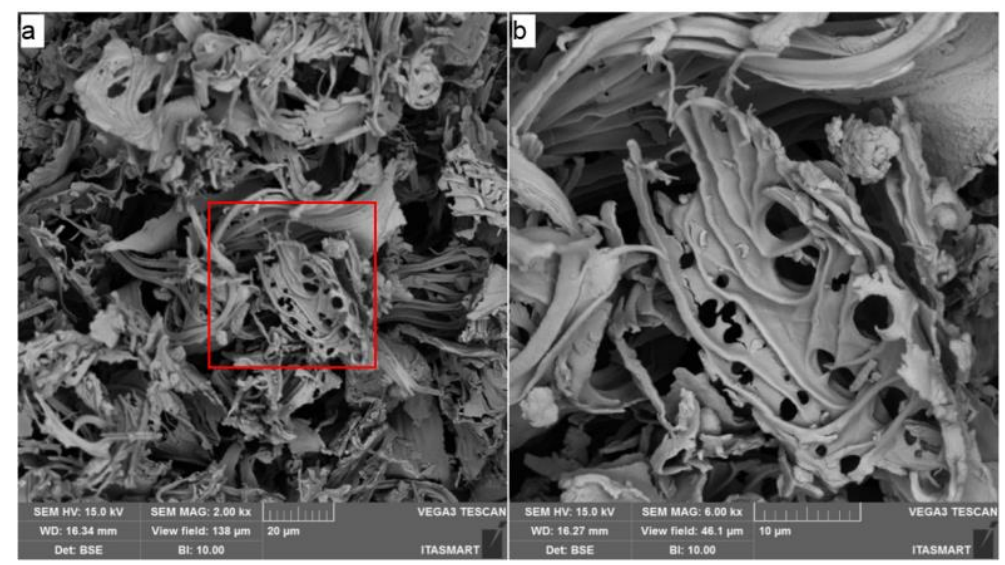

Figure 1. SEM images of the H-MO adsorbent at different magnifications: a) $\times 2000 \mathrm{e} \mathrm{b)} \times 6000$. 
The $\mathrm{N}_{2}$ adsorption-desorption isotherm of $\mathrm{H}-\mathrm{MO}$ adsorbent is presented in Figure 2, in which one can notice a typical behavior of a Type II isotherm with Type H3 hysteresis. Type II isotherms are given by the physisorption of most gases on nonporous or microporous adsorbents. The shape is the result of unrestricted monolayer-multilayer adsorption up to high $\mathrm{P} / \mathrm{P}_{0}$. Since the curvature in Figure 2 is more gradual, this is an indication of a great amount of overlap of monolayer coverage and the onset of multilayer adsorption. When $\mathrm{P} / \mathrm{P}_{0}=1$, the thickness of the adsorbed multilayer usually appears to increase without limit (Thommes et al., 2015). The open-loop presented in the $\mathrm{N}_{2}$ adsorption-desorption isotherm (Figure 2) is probably related to the pressure-dependent elastic deformation behavior, which is in accordance with low surface area adsorbents (Tang et al., 2017).

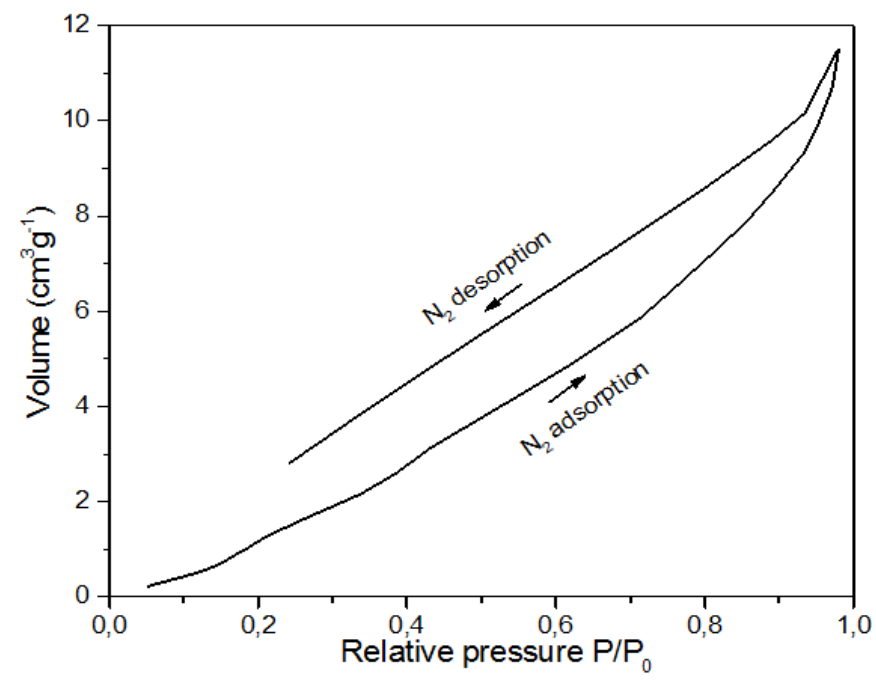

Figure 2. BET $\mathrm{N}_{2}$ adsorption-desorption isotherm at $196^{\circ} \mathrm{C}$ for $\mathrm{H}-\mathrm{MO}$.

The BET textural parameters of H-MO indicate a low specific surface area and total pore volume of $3.24 \mathrm{~m}^{2} \mathrm{~g}^{-1}$ and $0.010 \mathrm{~cm}^{3} \mathrm{~g}^{-1}$, respectively. These results are expected, as the seed husks have not been activated, and are in accordance with the literature relating to in natura $M$. oleifera seed husks. Cusioli et al. (2019) reported $1.52 \mathrm{~m}^{2} \mathrm{~g}^{-1}$ and $0.021 \mathrm{~cm}^{3} \mathrm{~g}^{-1}$, and Quesada et al. (2019) reported $1.2 \mathrm{~m}^{2} \mathrm{~g}^{-1}$ and $0.002 \mathrm{~cm}^{3} \mathrm{~g}^{-1}$ of specific surface area and total pore volume, respectively. The results are also in agreement with the behavior of a Type II isotherm, shown in Figure 2, of nonporous adsorbents.

The XRD pattern was conducted to determine the degree of crystalline or amorphous nature of the H-MO adsorbent and is presented in Figure 3(a). One can see, from the wide shape of the pattern, the material presents a predominance of an amorphous characteristic, suggesting a more disordered structure of the carbonaceous matrix. The main peak is detected at the $2 \theta$ value of around $22^{\circ}$, and the small peaks at around $16^{\circ}$ and $35^{\circ}$, and they are attributed to crystalline cellulose (Barnette et al., 2012). Similar peaks have been also found for modified M. oleifera seed husk (Bezerra et al., 2018) and Brazilian berry seeds (Eugenia uniflora) (Georgin et al., 2020).

The FTIR spectrum of H-MO is shown in Figure 3(b), exhibiting characteristic bands of lignocellulosic materials (Li et al., 2018). The broad peak in $3370 \mathrm{~cm}^{-1}$ indicates hydroxyl bonds O-H. Smaller peak in $2922 \mathrm{~cm}^{-1}$ could describe symmetric and asymmetric C-H stretching vibrations. The $1638 \mathrm{~cm}^{-1}$ peak can appear due to the interactions between water and $\mathrm{C}=\mathrm{O}$ or N-H stretching vibrations. Finally, the strong peak at $1032 \mathrm{~cm}^{-1}$ can be originated by $\mathrm{C}-\mathrm{O}$ bonds. The FTIR spectra also agrees with the literature relating to in natura M. oleifera seed husks (Tavares et al., 2017; Garcia-Fayos et al. 2016). One can thus conclude that, according to the FTIR spectra found, the surface of the adsorbent possesses a wide variety of 
functional groups that favor the adsorptive process.


Figure 3. a) X-ray diffractogram at $40 \mathrm{kV}$ and $30 \mathrm{~mA}$ and b) FTIR spectrum in the region of 4000 $650 \mathrm{~cm}^{-1}$ of H-MO.

\subsection{Effect of adsorbent dosage on adsorption capacity}

The effect of H-MO adsorbent dosage on the percentage removal of the adsorbate MB is shown in Figure 4. Initially, the percentage of MB removal increases sharply as the adsorbent dosage increases. Such an increase might be attributed to the higher number of available adsorbent active sites for adsorption (Shah et al., 2015). A maximum removal value of $98 \%$ is achieved at a dosage of $4 \mathrm{~g} \mathrm{~L}^{-1}$. However, considering that in the dosage of $1 \mathrm{~g} \mathrm{~L}^{-1}$ an $\mathrm{MB}$ removal greater than $90 \%$ was achieved, and that the increase in this dosage did not bring significant increases in removal, the dosage of $1 \mathrm{~g} \mathrm{~L}^{-1}$ of adsorbent is justified for economic purposes and was chosen for this study.

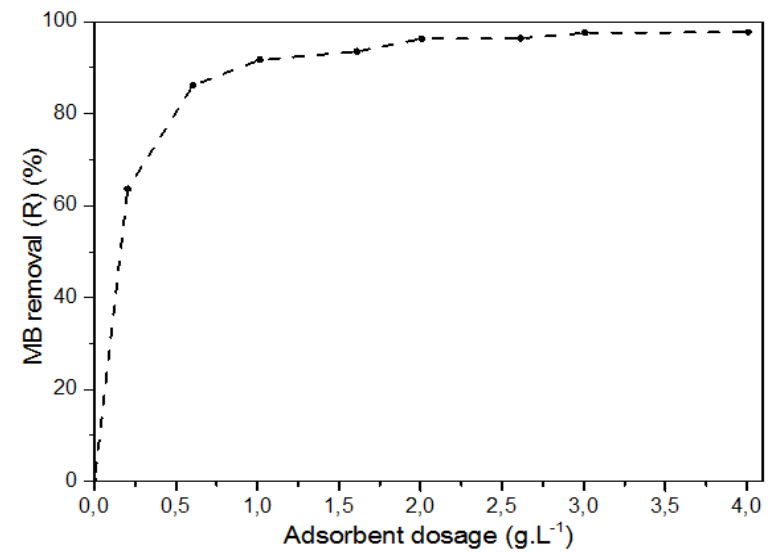

Figure 4. Effect of dosage on adsorption capacity of MB dye onto H-MO $\left(\mathrm{C}_{0}=50 \mathrm{mg} \mathrm{L}^{-}\right.$ ${ }^{1}, 24^{\circ} \mathrm{C}, \mathrm{V}=50 \mathrm{~mL}, \mathrm{pH}=7.0,1,200 \mathrm{~min}, 100$ $\mathrm{rpm})$.

\subsection{Point of zero charge (pHpzc) and effect of the solution pH on adsorption capacity}

Figure 5(a) shows the influence of $\mathrm{pH}$ value on the adsorption of $\mathrm{MB}$ by $\mathrm{H}-\mathrm{MO}$. One can observe that $\mathrm{pH}$ values increase from 5 to 9 to enhance the adsorption capacity. This effect is a result of the MB characteristics, as well as the H-MO surface properties when submitted to solutions with different $\mathrm{pH}$ values. Figure 5(b) shows that the $\mathrm{pH}$ PZC of H-MO is 6.6. The value of $\mathrm{pH}_{\mathrm{PZC}}$ is an important property to understand the adsorption process, since when the solution is at a $\mathrm{pH}$ value above $\mathrm{pH}_{\mathrm{PZC}}$, the functional groups of the adsorbent are deprotonated, resulting 
in a negatively charged surface, and contributing to the favorable adsorption of the cationic adsorbates. MB has a $p K_{a}$ value of 2.6 , so $\mathrm{MB}$ dye is in the cationic form at $\mathrm{pH}$ value greater than 2.6 (Sabnis, 2010). This effect enhances the electrostatic attraction between the negatively charged surface of $\mathrm{H}-\mathrm{MO}$ and positively charged MB dye. Considering the results obtained for the $\mathrm{pH}$ effect and $\mathrm{pH}_{\mathrm{PZC}}$, the maximum value of adsorption capacity on this study is reached at pH $9\left(\mathrm{q}_{\mathrm{e}}=52.02 \mathrm{mg} \mathrm{g}^{-1}\right)$, and this $\mathrm{pH}$ value was set for the other tests.

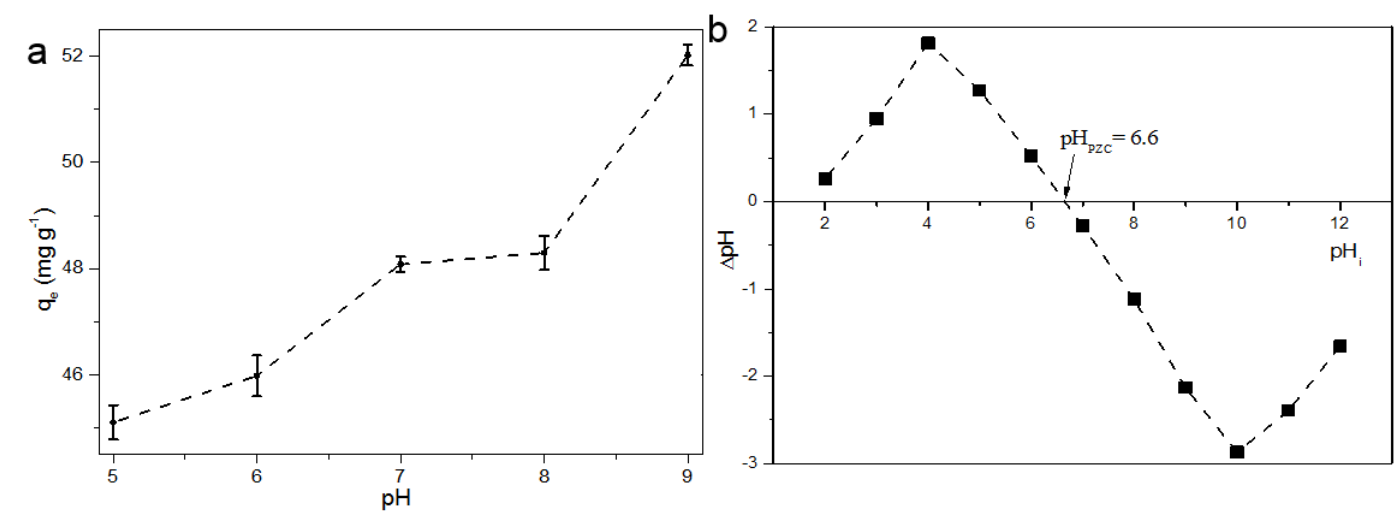

Figure 5. Adsorption of $\mathrm{MB}$ on $\mathrm{H}-\mathrm{MO}$ : a) $\mathrm{pH}$ effect $\left(\mathrm{C}_{0}=50 \mathrm{mg} \mathrm{L}^{-1}, 24^{\circ} \mathrm{C}, \mathrm{V}=50 \mathrm{~mL}\right.$, $\mathrm{H}-\mathrm{MO}$ dosage $\left.=1 \mathrm{~g} \mathrm{~L}^{-1}, 1,200 \mathrm{~min}, 100 \mathrm{rpm}\right)$ and $\mathrm{b}$ ) point of zero charge $\left(\mathrm{pH}_{\mathrm{PZC}}\right)$ by the salt addition method with $0.1 \mathrm{M} \mathrm{NaNO}$.

\subsection{Adsorption kinetics and modeling}

Adsorption kinetics were determined to evaluate the effect of contact time on MB dye adsorption on H-MO adsorbent. To better understand the MB dye adsorption process, the kinetic models of pseudo-first-order (Lagergren, 1898) and pseudo-second-order (Blanchard et al., 1984) were fitted to the experimental data using nonlinear method (Equations 4 and 5, respectively) and are represented in Figure 6.

$$
\begin{aligned}
q_{t} & =q_{e}\left(1-e^{-k_{1} t}\right) \\
q_{t} & =\frac{q_{e}^{2} k_{2} t}{1+k_{2} q_{e} t}
\end{aligned}
$$

Where $\mathrm{q}_{\mathrm{t}}$ is the amount of adsorbate uptake per mass of adsorbent at time $\mathrm{t}, \mathrm{q}_{\mathrm{e}}$ is the amount of adsorbate uptake per mass of adsorbent at equilibrium, $\mathrm{k}_{1}$ is the rate constant of the pseudofirst-order equation, and $\mathrm{k}_{2}$ is the rate constant of the pseudo-second-order equation.

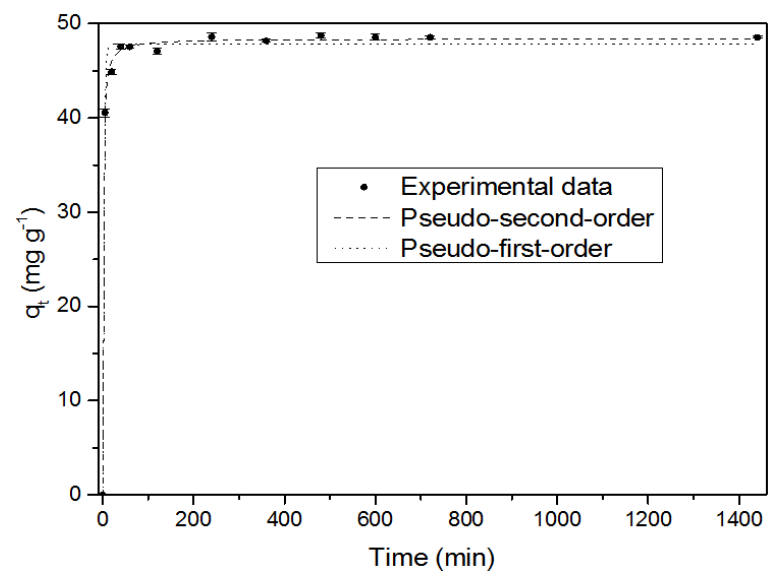

Figure 6. Kinetic curves for the adsorption of $\mathrm{MB}$ dye onto $\mathrm{H}-\mathrm{MO}\left(\mathrm{C}_{0}=50 \mathrm{mg} \mathrm{L}^{-1}, 24^{\circ} \mathrm{C}, \mathrm{V}=50\right.$ $\mathrm{mL}, \mathrm{H}-\mathrm{MO}$ dosage $\left.=1 \mathrm{~g} \mathrm{~L}^{-1}, \mathrm{pH}=9.0,100 \mathrm{rpm}\right)$. 
The adsorption kinetics presented in Figure 6 shows that H-MO adsorption capacity increases sharply at the beginning of the process, and it can be associated with the large number of active sites available. But the adsorption capacity reaches stability with a contact time of 240 $\min \left(\mathrm{q}_{\mathrm{e}}=48.6 \mathrm{mg} \mathrm{g}^{-1}\right)$. This stability of $\mathrm{q}_{\mathrm{e}}$ values indicates that equilibrium was achieved. This may be explained by the fact that almost all empty sites of the H-MO surface adsorbed the MB molecules available on the solution, making it difficult for new MB molecules to be adsorbed.

Correlation coefficients and parameters of the kinetic models for MB dye adsorption on $\mathrm{H}-\mathrm{MO}$ are presented in Table 1. The pseudo-second-order was better fitted to the experimental data, since the coefficient of determination $\left(\mathrm{R}^{2}\right)$ value was higher $(0.946)$; the chi-square $\left(\mathrm{X}^{2}\right)$ value, related to the error, was lower (0.326); and the adsorption capacity calculated (48.4 $\mathrm{mg}$ $\left.\mathrm{g}^{-1}\right)$ strongly agreed with that obtained experimentally $\left(48.6 \mathrm{mg} \mathrm{g}^{-1}\right)$. This means it is likely that both external and intraparticle diffusion steps control the total kinetics of the adsorption process (Ho and McKay, 1999). The pseudo-second-order model is a good fit to the kinetics data for most adsorption processes involving dyes (Yagub et al., 2014).

Table 1. Kinetic parameters of non-linear models for MB dye onto H-MO.

\begin{tabular}{ccc}
\hline Kinetic model & Parameters & Data \\
\hline Experimental & $\mathrm{q}_{\mathrm{e}}\left(\mathrm{mg} \mathrm{g}^{-1}\right)$ & 48.6 \\
\hline & $\mathrm{q}_{\mathrm{e}}\left(\mathrm{mg} \mathrm{g}^{-1}\right)$ & 47.8 \\
Pseudo-first-order & $\mathrm{K}_{1}\left(\mathrm{~min}^{-1}\right)$ & 0.375 \\
& $\mathrm{R}^{2}$ & 0.775 \\
& $\mathrm{X}^{2}$ & 1.368 \\
\hline Pseudo-second-order & $\mathrm{K}_{2}\left(\mathrm{~g} \mathrm{mg} \mathrm{g}^{-1} \mathrm{~min}^{-1}\right)$ & 0.020 \\
& $\mathrm{R}^{2}$ & 0.946 \\
& $\mathrm{X}^{2}$ & 0.326 \\
\hline
\end{tabular}

\subsection{Adsorption isotherms}

The adsorption isotherms were determined to better understand the interaction mechanisms between MB dye and the H-MO adsorbent. The isotherm models of Langmuir (Langmuir, 1918) and Freundlich (Freundlich, 1906) were fitted to the experimental data using nonlinear methods (Equations 6 and 7, respectively) and are represented in Figure 7.

$$
\begin{aligned}
& q_{e}=\frac{q_{\max } K_{L} C_{e}}{1+K_{L} C_{e}} \\
& q_{e}=K_{F} C_{e}^{\frac{1}{n}}
\end{aligned}
$$

Where $q_{e}$ is the amount of adsorbate uptake at equilibrium, $C_{e}$ is the equilibrium concentration of adsorbate, $q_{\max }$ is the maximum adsorption capacity, $K_{L}$ is adsorbent/adsorbate interaction constant, $K_{F}$ is Freundlich adsorption capacity constant, and $1 / n$ is the Freundlich intensity parameter, which indicates the magnitude of the adsorption driving force or the surface heterogeneity. 


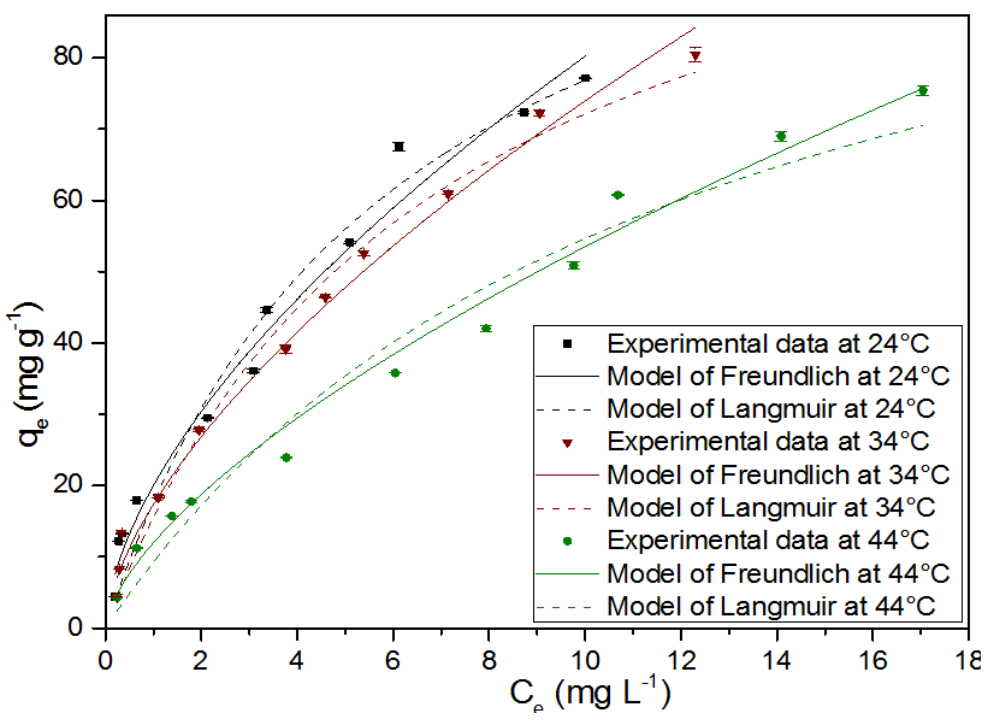

Figure 7. Adsorption isotherm for the adsorption of $\mathrm{MB}$ dye onto $\mathrm{H}-\mathrm{MO}\left(\mathrm{V}=50 \mathrm{~mL}, \mathrm{H}-\mathrm{MO}\right.$ dosage $=1 \mathrm{~g} \mathrm{~L}^{-1}, \mathrm{pH}=9.0,240$ min, $100 \mathrm{rpm})$.

The calculated parameters for such isotherms are shown in Table 2.

Table 2. Parameters of non-linear equilibrium isotherms models representing equilibrium adsorption data for MB onto H-MO.

\begin{tabular}{ccccc}
\hline & & \multicolumn{3}{c}{ Temperature $\left({ }^{\circ} \mathbf{C}\right)$} \\
\hline Isotherm model & Parameters & 24 & 34 & 44 \\
\hline \multirow{3}{*}{ Langmuir } & $\mathrm{q}_{\max }\left(\mathrm{mg} \mathrm{g}^{-1}\right)$ & 122.7 & 120.9 & 119.8 \\
& $\mathrm{~K}_{\mathrm{L}}\left(\mathrm{L} \mathrm{mg}^{-1}\right)$ & 0.17 & 0.15 & 0.08 \\
& $\mathrm{R}^{2}$ & 0.97 & 0.98 & 0.97 \\
& $\mathrm{X}^{2}$ & 21.98 & 11.29 & 18.93 \\
\hline \multirow{4}{*}{ Freundlich } & $\mathrm{K}_{\mathrm{F}}\left(\left(\mathrm{mg} \mathrm{g}^{-1}\right)\left(\mathrm{mg} \mathrm{L}^{-1}\right)^{-1 / \mathrm{n}}\right)$ & 20.01 & 17.35 & 11.96 \\
& $1 / \mathrm{n}$ & 0.60 & 0.63 & 0.65 \\
& $\mathrm{R}^{2}$ & 0.98 & 0.99 & 0.98 \\
& $\mathrm{X}^{2}$ & 13.23 & 6.25 & 8.14
\end{tabular}

The separation factor or equilibrium parameter $R_{L}$ is derived from the Langmuir model and can be calculated according to Equation 8 (Hall et al., 1966):

$$
R_{L}=\frac{1}{1+K_{L} C_{0}}
$$

Where $K_{L}$ is the Langmuir equilibrium constant, and $\mathrm{C}_{0}$ is the initial adsorbate concentration. The calculated values of $R_{L}$ are in the range of 0.06 to $0.56\left(24^{\circ} \mathrm{C}\right), 0.07$ to 0.59 $\left(34^{\circ} \mathrm{C}\right)$, and 0.11 to $0.72\left(44^{\circ} \mathrm{C}\right)$.

According to Figure 7, the adsorption capacity of MB dye increased with increasing equilibrium concentration $\left(\mathrm{C}_{\mathrm{e}}\right)$, with the adsorption isotherms showing a typical concave shape. In addition to that, $0<R_{L}<1$ and $0<1 / n<1$ (Table 2). All these parameters indicate the adsorption is favorable for the studied temperatures $\left(24^{\circ} \mathrm{C}, 34^{\circ} \mathrm{C}\right.$ and $\left.44^{\circ} \mathrm{C}\right)$.

The correlation coefficients and parameters of the adsorption models for $\mathrm{MB}$ dye adsorption on H-MO presented in Table 2 indicate that both models were well adjusted for the adsorption processes in the studied temperatures, with a coefficient of determination $\mathrm{R}^{2}$ ranging from 0.97 to 0.99 . However, the chi-square $\left(\chi^{2}\right)$ values were lower from the Freundlich model 
(6.25 to 13.23) when compared to Langmuir model (11.29 to 21.98) for the three temperatures studied, indicating that the Freundlich model was better fitted to the experimental data. The Freundlich model assumes the adsorbent surface energy is heterogeneous with the strongest binding sites being occupied first and the binding force decreasing with the increasing degree of site occupancy (Febrianto et al., 2009). A better suitability of the Freundlich model compared to the Langmuir model for the adsorption of MB dye was also reported by Tuli et al. (2020) using activated tea waste carbon, and by Khodaie et al. (2013) using activated corn husk carbon.

From the temperature effect on the equilibrium curves shown in Figure 7 and Table 2, one may notice the temperature increase provided a little decrease in adsorption capacity $\left(\mathrm{q}_{\max }\right)$, from $122.7\left(24^{\circ} \mathrm{C}\right)$ to $119.8 \mathrm{mg} \mathrm{g}^{-1}\left(44^{\circ} \mathrm{C}\right)$.

The adsorption capacity of various adsorbents is commonly compared by the parameter $q_{\text {max }}$. Table 3 shows the maximum adsorption capacity of different adsorbents used for MB dye removal. The value obtained for $q_{\max }$ in this study is higher than those of other adsorbents produced with agricultural wastes. $M$. oleifera seed husk is shown to be a good adsorbent for MB dye, although the result for $q_{\max }$ is quite lower than those obtained with activated carbon. However, the adsorbent used in this study does not require high temperatures during its processing or activation steps, meaning that this material has a lower operating cost than activated carbon.

Table 3. Comparison of adsorption capacities of different adsorbents for MB dye removal.

\begin{tabular}{lcccl}
\hline Adsorbent & Activation & $\begin{array}{c}\text { T } \\
\left({ }^{\circ} \mathbf{C}\right)\end{array}$ & $\begin{array}{c}\mathbf{q} \text { max } \\
\left(\mathbf{m g ~ g}^{-1}\right)\end{array}$ & Reference \\
\hline M. oleifera seed husks & Raw & 24 & 122.7 & This work \\
Apple pomace & Raw & 25 & 107.6 & Bonetto et al. $(2021)$ \\
Husk of Lathyrus sativus & Raw & 30 & 98.33 & Gosh et al. $(2021)$ \\
Husk of Lathyrus sativus & Phosphoric acid & 30 & 113.25 & Gosh et al. $(2021)$ \\
Husk of Lathyrus sativus & Sulfuric acid & 30 & 104.28 & Gosh et al. $(2021)$ \\
E. grandis lignin & Raw & 25 & 31.97 & Cemin et al. $(2021)$ \\
Tea waste & KOH / 500 ${ }^{\circ} \mathrm{C}$ & 25 & 357.14 & Tuli et al. $(2020)$ \\
Brazilian berry seeds $($ E. uniflora $)$ & Raw & 55 & 189.6 & Georgin et al. $(2020)$ \\
Sorghum husk & Magnetic & 30 & 30.04 & Adeogun et al. $(2019)$ \\
\hline
\end{tabular}

\subsection{Thermodynamic parameters}

Thermodynamic adsorption plays a key role in predicting viability, spontaneity, and adsorptive mechanisms (Tran et al., 2016). The thermodynamic parameters can be computed according to the laws of thermodynamics, using the following Equation 9:

$$
\Delta G^{\circ}=-R T \ln K_{C}
$$

The relationship between the three thermodynamic parameters, Gibbs energy $\left(\Delta G^{\circ}\right)$, enthalpy $\left(\Delta \mathrm{H}^{\circ}\right)$, and entropy $\left(\Delta \mathrm{S}^{\circ}\right)$ is described by Equation 10:

$$
\Delta G^{\circ}=\Delta H^{\circ}-T \Delta S^{\circ}
$$

By substituting Equation 9 in Equation 10, one can obtain Equation 11, known as van't Hoff equation.

$$
\ln K_{C}=-\frac{\Delta H^{\circ}}{R T}+\frac{\Delta S^{\circ}}{R}
$$


Where $\mathrm{R}$ is the universal constant $\left(8.314 \mathrm{~J} \mathrm{~mol}^{-1} \mathrm{~K}^{-1}\right)$ and $\mathrm{T}$ is the solution temperature $(\mathrm{K})$. Enthalpy $\left(\Delta \mathrm{H}^{\circ}\right)$ and entropy $\left(\Delta \mathrm{S}^{\circ}\right)$ changes were determined from the slope and intercept, respectively, of a plot of $\ln K_{C}$ versus $1 /_{\mathrm{T}}$ (Equation 11). Gibbs energy change $\left(\Delta \mathrm{G}^{\circ}\right)$ was directly calculated from Equation 9.

The dimensionless thermodynamic equilibrium constant $K_{C}$ in Equations 9 and 11 was calculated from the Freundlich adsorption isotherm constant $K_{F}$, since this model was better fitted to the experimental data, through Equation 12 (Tran et al., 2016; Ghosal and Gupta, 2015).

$$
K_{C}=\frac{K_{F} \rho}{1000}\left(\frac{10^{6}}{\rho}\right)^{(1-1 / n)}
$$

Where $\rho$ is the density of pure water (assumed as $\sim 1 \mathrm{~g} \mathrm{~mL}^{-1}$ ) and $1 / n$ is the Freundlich intensity parameter.

The MB adsorption thermodynamic parameters onto H-MO are shown in Table 4. Evidence that suggests the appropriate application of the Freundlich constant $K_{F}$ in estimating the thermodynamic parameters is the high determination coefficient of the van't Hoff equation $\left(\mathrm{R}^{2}=0.991\right)$. A critical factor for determining the degree of spontaneity of the adsorption process is the Gibbs energy variation: the negative values of Gibbs energy $\left(\Delta \mathrm{G}^{\circ}\right)$ shown in Table 4 denote that the adsorption is energetically favorable; in other words, the process tends to be spontaneous. In addition, the decreasing of the magnitude of $\Delta \mathrm{G}^{\circ}$ with temperature means the process tends to a less thermodynamically favorable process at higher temperatures, which can be confirmed by the enthalpy value. Similar results were found for the adsorption of MB by apple pomace (Bonetto et al., 2021).

Table 4. Thermodynamic parameters for adsorption of MB dye onto H-MO.

\begin{tabular}{cccccc}
\hline $\mathbf{T}\left({ }^{\circ} \mathbf{C}\right)$ & $\mathbf{K}_{\mathbf{C}}$ & $\Delta \mathbf{G}^{\circ}\left(\mathbf{k J ~ m o l}{ }^{-1}\right)$ & $\Delta \mathbf{H}^{\circ}\left(\mathbf{k J ~ m o l}^{-\mathbf{1}}\right)$ & $\Delta \mathbf{S}^{\circ}\left(\mathbf{J ~ m o l}^{-\mathbf{1}} \mathbf{K}^{-\mathbf{1}}\right)$ & van't Hoff equation \\
\hline 24 & 4.82 & -3.88 & & & \\
34 & 2.90 & -2.72 & -45.80 & -140.81 & $\mathrm{Y}=5,508 \mathrm{x}-16.94$ \\
44 & 1.49 & -1.06 & & & $\mathrm{R}^{2}=0.991$ \\
\hline
\end{tabular}

The negative value of the enthalpy parameter $\left(\Delta \mathrm{H}^{\circ}\right)$ shown in Table 4 indicates the adsorption process is exothermic, which means the decrease in temperature results in an increase in adsorption capacity $\left(q_{e}\right)$ (Table 2$)$ and in the equilibrium constant $\left(K_{C}\right)$ (Table 4$)$. Furthermore, the type of interaction can be assigned, to a certain extent, by the magnitude of enthalpy change. Physisorption, such as van der Waals interactions, is usually lower than $20 \mathrm{~kJ}$ $\mathrm{mol}^{-1}$. Electrostatic interaction ranges from $20-80 \mathrm{~kJ} \mathrm{~mol}^{-1}$ and they are also frequently classified as physisorption, while a value in the range of $80-450 \mathrm{~kJ} \mathrm{~mol}^{-1}$ indicates a chemisorption (Alencar et al., 2012; Ghosh et al., 2021). Therefore, the typical physisorption enthalpy value for this study $\left(\Delta \mathrm{H}^{\circ}=-45.8 \mathrm{~kJ} \mathrm{~mol}^{-1}\right)$ may be related to the sum of different molecular interactions, such as hydrogen bonding and electrostatic interactions between active sites on the adsorbent and the cationic dye. An exothermic adsorption process was also reported elsewhere (Ghosh et al., 2021). Finally, the negative sign in entropy $\left(\Delta \mathrm{S}^{\circ}\right)$ indicates the organization of the adsorbate at the solid/solution interface during the adsorption process becomes less random, also implying the adsorption phenomenon involves an associative mechanism. 


\subsection{Adsorption mechanism}

Figure 8 shows the proposed interaction between the MB and the H-MO. Based on the dataset discussed in this study, one could show that MB dye removal by H-MO occurs mainly due to electrostatic interactions, which is evidenced by the adsorption capacity enhancement in $\mathrm{pH}$ values above $\mathrm{pH}$ PZC. Similar conclusions were reported by other authors who investigated the adsorption of MB by agricultural wastes (Bonetto et al., 2021; Ghosh et al., 2021). Additionally, the value found for $\Delta \mathrm{H}^{\circ}\left(-45.8 \mathrm{~kJ} \mathrm{~mol}^{-1}\right)$ reinforces that these interactions are in the range of electrostatic interaction, also classified as physisorption, with no sharing or exchange of electrons.

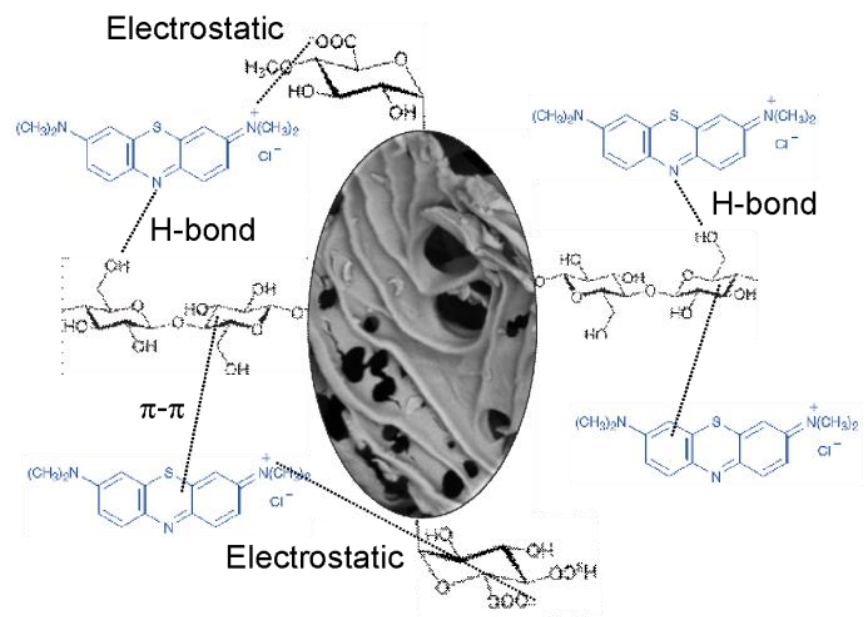

Figure 8. Proposed interaction for MB dye and H-MO adsorption system.

Moreover, $\mathrm{H}-\mathrm{MO}$ composition presents several oxygenated functional groups, as presented by crystalline cellulose shown in XRD pattern (Figure 3(a)), and by $\mathrm{O}-\mathrm{H}, \mathrm{C}=\mathrm{O}, \mathrm{N}-\mathrm{H}$ and $\mathrm{C}-\mathrm{O}$ groups by FTIR spectrum (Figure 3(b)), which can also interact with MB molecules through dipole-dipole hydrogen bonds (Tran et al. 2017). The incidence of aromatic rings, both in the chemical structure of $\mathrm{H}-\mathrm{MO}$ (cellulose) and in MB dye molecules, can also favor $\pi-\pi$ interactions, contributing to the adsorption process (Cemin et al., 2021).

\section{CONCLUSIONS}

This study evaluated the adsorption capacity of methylene blue (MB) dye using Moringa oleifera seed husks (H-MO). The kinetic model that showed the best fit was the pseudo-secondorder model, and the isotherm that presented the best fit was a Freundlich model, indicating a favorable adsorption process ( $1 / n$ from 0.60 to 0.63 ) with a maximum adsorption capacity of $\mathrm{MB}$ by $\mathrm{H}-\mathrm{MO}$ of $122.7 \mathrm{mg} \mathrm{g}^{-1}$ at $24^{\circ} \mathrm{C}$, higher than some recently published studies in the literature. The thermodynamic data indicated that the adsorption process is spontaneous $\left(\Delta \mathrm{G}^{\circ}\right.$ from -3.88 to $\left.-1.06 \mathrm{~kJ} \mathrm{~mol}^{-1}\right)$ and exothermic $\left(\Delta \mathrm{H}^{\circ}\right.$ of $\left.-45.80 \mathrm{KJ} \mathrm{mol}^{-1}\right)$, showing that lower temperatures favor $\mathrm{MB}$ adsorption by $\mathrm{H}-\mathrm{MO}$ and that adsorption is controlled by physical forces. The disadvantage of the adsorbent preparation method of presenting low surface area $\left(3.24 \mathrm{~m}^{2} \mathrm{~g}^{-1}\right)$ and total pore volume $\left(0.010 \mathrm{~cm}^{3} \mathrm{~g}^{-1}\right)$ were expected, as the seed husks have not been previously activated, but were compensated by the electrostatic attraction at $\mathrm{pH}$ values above 6.6 (pHPZC) and by dipole-dipole hydrogen bonds and $\pi-\pi$ interactions due to its surface composition, at any $\mathrm{pH}$, resulting in a favorable adsorption process. Thus, from the results obtained, one can conclude that $\mathrm{H}-\mathrm{MO}$ has promise for use in the adsorption process to remove MB in aqueous solution. Considering that seed husks are an agricultural waste, their use as 
adsorbents of agricultural waste is a promising and low-cost option, which can also minimize the environmental impacts of their improper disposal.

\section{ACKNOWLEDGEMENTS}

The authors are grateful to National Council for Scientific and Technological Development (CNPq) - [grant PIBIC 123798/2020-5] for the partial financial support.

\section{REFERENCES}

ADEOGUN, A. I.; AKANDE, J. A.; IDOWU, M. A.; KAREEM, S. O. Magnetic tuned sorghum husk biosorbent for effective removal of cationic dyes from aqueous solution: isotherm, kinetics, thermodynamics and optimization studies. Applied Water Science, v. 9, n. 160, 2019. https://doi.org/10.1007/s13201-019-1037-2

ALENCAR, W. S.; LIMA, E. C.; ROYER, B.; DOS SANTOS, B. D.; CALVETE, T.; DA SILVA, E. A. et al. Application of aqai stalks as biosorbents for the removal of the dye procion blue MX-R from aqueous solution. Separation Science and Technology, v. 47 n. 3, p. 513-526, 2012. https://doi.org/10.1080/01496395.2011.616568

ARAÚJO, C. S. T; CARVALHO, D. C; REZENDE, H. C.; ALMEIDA, I. L. S.; COELHO, L. M.; COELHO, N. M. M. et al. Bioremediation of Waters Contaminated with Heavy Metals Using Moringa oleifera Seeds as Biosorbent. In: PATIL, Y. B.; RAO, P. (eds.). Applied Bioremediation - Active and Passive Approaches. London: IntechOpen, 2013. http://dx.doi.org/10.5772/56157

ARAUJO, L. A.; BEZERRA, C. O.; CUSIOLI, L. F.; SILVA, M. F.; NISHIB, L.; GOMES, R. G. et al. Moringa oleifera biomass residue for the removal of pharmaceuticals from water. Journal of Environmental Chemical Engineering, v. 6, n. 6, p. 7192-7199, 2018. https://doi.org/10.1016/j.jece.2018.11.016

BAKATULA, E. N.; RICHARD, D.; NECULITA, C. M.; ZAGURI, G. J. Determination of point of zero charge of natural organic materials. Environmental Science and Pollution Research, v. 25, p. 7823-7833, 2018. https://doi.org/10.1007/s11356-017-1115-7

BARNETTE, A. L.; LEE, C.; BRADLEY, L. C.; SCHREINER, E. P.; PARK, Y. B.; SHIN, H. et al. Quantification of crystalline cellulose in lignocellulosic biomass using sum frequency generation (SFG) vibration spectroscopy and comparison with other analytical methods. Carbohydrate Polymers, v. 89, n. 3, p. 802-809, 2012. https://doi.org/10.1016/j.carbpol.2012.04.014

BEZERRA, C. O.; CUSIOLI, L. F.; QUESADA, H. B.; NISHI, L.; MANTOVANI, D.; VIEIRA, M. F. et al. Assessment of the use of Moringa oleifera seed husks for removal of pesticide diuron from contaminated water. Environmental Technology, v. 41, n. 2, p. 191-201, 2018. https://doi.org/10.1080/09593330.2018.1493148

BLANCHARD, G.; MAUNAYE, M.; MARTIN, G. Removal of heavy metals from waters by means of natural zeolites. Water Research, v. 18 n. 12, p. 1501-1507, 1984. https://doi.org/10.1016/0043-1354(84)90124-6

BONETTO, L. R.; CRESPO, J. S.; GUÉGAN, R.; ESTEVES, V. I.; GIOVANELA, M. Removal of methylene blue from aqueous solutions using a solid residue of the apple juice industry: Full factorial design, equilibrium, thermodynamics and kinetics aspects. Journal of Molecular Structure, v. 1224, n. 15, p. 129296, 2021. https://doi.org/10.1016/j.molstruc.2020.129296 
CEMIN, A.; FERRARINI, F.; POLETTO, M.; BONETTO, L. R.; BORTOLUZ, J.; LEMÉE, L. et al. Characterization and use of a lignin sample extracted from Eucalyptus grandis sawdust for the removal of methylene blue dye. International Journal of Biological $\begin{array}{lllllll}\text { Macromolecules, } & \text { v. } \quad 170, \quad \text { n. } & 15, \quad \text { p. }\end{array}$ https://doi.org/10.1016/j.ijbiomac.2020.12.155

CUSIOLI, L. F.; BEZERRA, C. O.; QUESADA, H. B.; BAPTISTA, A. T. A.; NISHI, L.; VIEIRA, M. F. et al. Modified Moringa oleifera Lam. Seed husks as low-cost biosorbent for atrazine removal. Environmental Technology, v. 42, p. 1092-1103, 2019. https://doi.org/10.1080/09593330.2019.1653381

FEBRIANTO, J.; KOSASIH, A. N.; SUNARSO, J.; JU, Y. H.; INDRASWATI, N.; ISMADJI S. Equilibrium and kinetic studies in adsorption of heavy metals using biosorbent: a summary of recent studies. Journal of Hazardous Materials, v. 162, n. 2-3, p. 616-645, 2009. https://doi.org/10.1016/j.jhazmat.2008.06.042

FREUNDLICH, H. Über die Adsorption in Lösungen. Zeitschrift für Physikalische Chemie, v. 57, p. 385-471, 1906.

GARCIA-FAYOS, B.; ARNAL, J. M.; PIRIS, J.; SANCHO, M. Valorization of Moringa oleifera seed husk as biosorbent: isotherm and kinetics studies to remove cadmium and copper from aqueous solutions. Desalination and Water Treatment, v. 57, n. 48-49, p. 23382-23396, 2016. https://doi.org/10.1080/19443994.2016.1180473

GEORGIN, J.; FRANCO, D. S. P.; NETTO, M. S.; ALLASIA, D.; OLIVEIRA, M. L. S.; DOTTO, G. L. Treatment of water containing methylene by biosorption using Brazilian berry seeds (Eugenia uniflora). Environmental Science and Pollution Research, v. 27, p. 20831-20843, 2020. https://doi.org/10.1007/s11356-020-08496-8

GHOSH, I.; KAR, S.; CHATTERJEE, T.; BAR, N.; DAS, S. K. Removal of methylene blue from aqueous solution using Lathyrus sativus husk: Adsorption study, MPR and ANN modeling. Process Safety and Environmental Protection, v. 149, n. 345-361, 2021. https://doi.org/10.1016/j.psep.2020.11.003

GHOSAL, P. S.; GUPTA, A. K. An insight into thermodynamics of adsorptive removal of fluoride by calcined Ca-Al-( $\left.\mathrm{NO}_{3}\right)$ layered double hydroxide. RSC Advances, v. 5, n. 128, p. 105889-105900, 2015. https://doi.org/10.1039/C5RA20538G

GUPTA, V. K.; CARROTT, P. J. M.; RIBEIRO CARROTT, M. M. L.; SUHAS. Low-cost adsorbents: growing approach to wastewater treatment - a review. Critical Reviews in Environmental Science and Technology, v. 39, n. 10, p. 783-842, 2009. https://doi.org/10.1080/10643380801977610

HALL, K. R.; EAGLETON, L. C.; ACRIVOS, A.; VERMEULEN, T. Pore- and solid-diffusion kinetics in fixed-bed adsorption under constant-pattern conditions. Industrial \& Engineering Chemistry Fundamentals, v. 5, n. 2, p. 212-223, 1966. https://doi.org/10.1021/i160018a011

HO, Y. S.; MCKAY, G. Pseudo-second order model for sorption processes. Process Biochemistry, v. 34, n. 5, p. 451-465, 1999. https://doi.org/10.1016/S00329592(98)00112-5

KANSAL, S. K.; KUMARI, A. Potential of $M$. oleifera for the treatment of water and wastewater. Chemical Reviews, v. 114, n. 9, p. 4993-5010, 2014. https://doi.org/10.1021/cr400093w 
KHODAIE, M.; GHASEMI, N.; MORADI, B.; RAHIMI, M. Removal of methylene blue from wastewater by adsorption onto $\mathrm{ZnCl}_{2}$ activated corn husk carbon equilibrium studies. Journal of Chemistry, v. 2013, p. 383985, 2013. https://doi.org/10.1155/2013/383985

LAGERGREN, S. About the theory of so-called adsorption of soluble substances. Kungl. Svenska vetenskapsakademiens handlingar, v. 24, n. 4, p. 1-39, 1898.

LANGMUIR, I. The adsorption of gasses on plane surfaces of glass, mica and platinum. Journal of the American Chemical Society, v. 40, n. 9, p. 1361-1403, 1918.

LI, X.; WEI, Y.; XU, J.; HE, Y. Quantitative visualization of lignocellulose components in transverse sections of moso bamboo based on FTIR macro- and micro-spectroscopy coupled with chemometrics. Biotechnology for Biofuels, v. 11, n. 263, 2018. https://doi.org/10.1186/s13068-018-1251-4

OKOYA, A. A.; OLAIYA, O. O.; AKINYELE, A. B.; OCHOR, N. O. Efficacy of Moringa oleifera Seed Husk as Adsorptive Agent for Trihalomethanes from a Water Treatment Plant in Southwestern, Nigeria. Journal of Chemistry, v. 2020, p. 3450954, 2020. https://doi.org/10.1155/2020/3450954

QUESADA, H. B.; CUSIOLI, L. F.; BEZERRA, C. O.; BAPTISTA, A. T. A.; NISHI, L.; GOMES, R. G. et al. Acetaminophen adsorption using a low-cost adsorbent prepared from modified residues of Moringa oleifera Lam. seed husks. Journal of Chemical


https://doi.org/10.1002/jctb.6121

RECK, I. M.; PAIXÃO, R. M.; BERGAMASCO, R.; VIEIRA, M. F.; VIEIRA, M. A. S. Removal of tartrazine from aqueous solutions using adsorbents based on activated carbon and Moringa oleifera seeds. Journal of Cleaner Production, v. 171, n. 10, p. 85-97, 2018. https://doi.org/10.1016/j.jclepro.2017.09.237

RIBEIRO, J. V. M.; ANDRADE, P. V.; REIS A. G. Moringa oleifera seed as a natural coagulant to treat low-turbidity water by in-line filtration. Revista Ambiente \& Água, v. 14, n. 6, p. e2442, 2019. https://doi.org/10.4136/ambi-agua.2442

SABNIS, R. W. Biological Dyes and Stains Synthesis and Industrial Applications. Hoboken : John Wiley \& Sons, 2010.

SHAH, I.; ADNAN, R.; NGAH, W. S. W; MOHAMED, N. Iron impregnated activated carbon as an efficient adsorbent for the removal of methylene blue: regeneration and kinetics $\begin{array}{lllllll}\text { studies. } & \text { PLoS One, v. } & \text { 10, } & \text { p. } & \text { 0122603, }\end{array}$ https://doi.org/10.1371/journal.pone.0122603

TANG, J.; YANG, M.; YU, F.; CHEN, X.; TAN, L.; WANG, G. 1-Octadecanol@ hierarchical porous polymer composite as a novel shape-stability phase change material for latent heat thermal energy storage. Applied Energy, v. 187, p. 514-522, 2017. https://doi.org/10.1016/j.apenergy.2016.11.043

TAVARES, F. O.; PINTO, L. A. M.; BASSETTI, F. J.; VIEIRA, M. F.; BERGAMASCO, R.; VIEIRA, M. A. S. Environmentally friendly biosorbents (husks, pods and seeds) from Moringa oleifera for $\mathrm{Pb}(\mathrm{II})$ removal from contaminated water. Environmental $\begin{array}{lllllll}\text { Technology, } & \text { v. } 38, \quad \text { n. } 24, & \text { p. } & 3145-3155,\end{array}$ https://doi.org/10.1080/09593330.2017.1290150 
THOMMES, M.; KANEKO, K.; NEIMARK, A. V.; OLIVIER, J. P.; RODRIGUEZREINOSO, F.; ROUQUEROL, J. et al. Physisorption of gasses, with special reference to the evaluation of surface area and pore size distribution (IUPAC Technical Report). Pure and Applied Chemistry, v. 87, p. 1051-1069, 2015. https://doi.org/10.1515/pac-20141117

TRAN, H. N.; YOU, S. J.; CHAO, H. P. Thermodynamic parameters of cadmium adsorption onto orange peel calculated from various methods: A comparison study. Journal of Environmental Chemical Engineering, v. 4, n. 3, p. 2671-2682, 2016. https://doi.org/10.1016/j.jece.2016.05.009

TRAN, H. N.; YOU, S. J.; NGUYEN, T. V.; CHAO, H. P. Insight into adsorption mechanism of cationic dye onto biosorbents derived from agricultural wastes. Chemical Engineering Communications, v. 204, n. 9, p. 1020-1036, 2017. https://doi.org/10.1080/00986445.2017.1336090

TULI, F. J.; HOSSAIN, A.; FAZLE KIBRIA, A. K. M.; TAREQ, A. R. M.; MAMUN, S. M. M. A.; ATIQUE ULLAH, A. K. M. Removal of methylene blue from water by low-cost activated carbon prepared from tea waste: A study of adsorption isotherm and kinetics. Environmental Nanotechnology, Monitoring \& Management, v. 14, p. 100354, 2020. https://doi.org/10.1016/j.enmm.2020.100354

UEDA YAMAGUCHI, N.; CUSIOLI, L. F.; QUESADA, H. B.; CAMARGO FERREIRA, M. E.; FAGUNDES-KLEN, M. R.; SALCEDO VIEIRA, A. M. et al. A review of Moringa oleifera seeds in water treatment: Trends and future challenges. Process Safety and

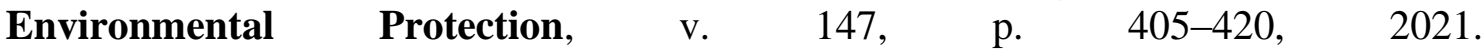
https://doi.org/10.1016/j.psep.2020.09.044

VEGA ANDRADE, P.; PALANCA, C. F.; OLIVEIRA, M. A. C.; ITO, C. Y. K.; REIS, A. G. Use of Moringa oleifera seed as a natural coagulant in domestic wastewater tertiary treatment: Physicochemical, cytotoxicity and bacterial load evaluation. Journal of $\begin{array}{lllllll}\text { Water Process } & \text { Engineering, } & \text { v. } & 4021 .\end{array}$ https://doi.org/10.1016/j.jwpe.2020.101859

VILLASEÑOR-BASULTO, D. L.; ASTUDILLO-SÁNCHEZ, P. D.; REAL-OLVERA, J.; BANDALA, E. R. Wastewater treatment using Moringa oleifera Lam seeds: A review. Journal of Water Process Engineering, v. 23, p. 151-164, 2018. https://doi.org/10.1016/j.jwpe.2018.03.017

YAGUB, M. T.; SEN, T. K.; AFROZE, S.; ANG, H. M. Dye and its removal from aqueous solution by adsorption: a review. Advances in Colloid and Interface Science, v. 209, p. 172-184, 2014. https://doi.org/10.1016/j.cis.2014.04.002

WARHURST, A. M.; RAGGETT, S. L.; MCCONNACHIE, G. L.; POLLARD, S. J. T.; CHIPOFYA, V.; CODD, G.A. Adsorption of the cyanobacterial hepatotoxin microcystinLR by a low-cost activated carbon from the seed husks of the pan-tropical tree, Moringa oleifera. Science of The Total Environment, v. 207, n. 2-3, p. 207-211, 1997. https://doi.org/10.1016/S0048-9697(97)00260-X. 